\title{
Corporate Groups within the Legal Framework of the European Union: The Group-Related Aspects of the SUP Proposal and the EU Freedom of Establishment
}

by

Christoph TeichmanN*

\begin{abstract}
Many people see the typical corporate group as a big and powerful multi-national economic entity. In company law, however, the notion of a group is not related to the size of the business. Even smaller businesses often operate through groups. In order to support cross border activities of Small and Medium Sized Enterprises (SMEs), the proposal for a singlemember company (Societas Unius Personae - SUP) aims at facilitating the incorporation and management of subsidiaries. As will be shown in this article, there is an interconnection between the European freedom of establishment and the functioning of cross-border corporate groups. The latter aspect is also addressed by particular provisions in the SUP Proposal dealing with the internal organization of an SUP. There remains, however, an important gap, since the SUP Proposal does not regulate the question as to whether the parent SME is allowed to manage its SUP subsidiaries in the interest of the group. The article concludes that the aspect of a diligent cross-border group management needs further attention by the EU legislator.
\end{abstract}

I. Group-Related Aspects of the SUP Proposal . . . . . . . . . . . . . . . . . 203

1. Small and Medium-Sized Enterprises as the Major Beneficiaries . . . . . 203

2. Facilitating the Establishment of Subsidiaries . . . . . . . . . . . 205

3. Facilitating the Management of Subsidiaries . . . . . . . . . . . . 206

II. The two Perspectives on Group Law . . . . . . . . . . . . . . . . . . . . . 208

1. Protective Function of Group Law . . . . . . . . . . . . . . . . . . . 209

2. Enabling Function of Group Law . . . . . . . . . . . . . . 212

III. Cross-border Business Structures and EU Freedom of Establishment . . . . 214

1. Cross-Border Groups in the Framework of the TFEU . . . . . . . . . . 214

2. The Choice between Branch and Subsidiary . . . . . . . . . . . . 216

3. EU Competence to Act by Means of a Directive . . . . . . . . . . . . 220

IV. Enabling Provisions for Managing Cross-Border Groups . . . . . . . . . . . . 224

1. Lessons to be Learned from the EPC Debate . . . . . . . . . . . . . . 224

* Professor, University of Würzburg. 
2. The SUP Proposal as Enabling Law for Corporate Groups . . . . . . . 225

3. EU Initiative on the Group Interest . . . . . . . . . . . . . . . 228

V. Conclusion . . . . . . . . . . . . . . . . . . . . . . . . . . . . . . 229

\section{Group-Related Aspects of the SUP Proposal}

The recent proposal to amend the directive on single-member companies (SUP Proposal) ${ }^{1}$ is strongly related to the group aspect of company law. It shall support SMEs in order to be more active in cross-border business (see below 1). In order to attain this objective, the European Commission proposes a standardized incorporation procedure (see below 2 ) and aims at harmonizing key elements for the management of a single-member company (see below 3 ). ${ }^{2}$ A single-member company formed in accordance with the directive shall obtain the name Societas Unius Personae (SUP).

\section{Small and Medium-Sized Enterprises as the Major Beneficiaries}

The objectives of the SUP Proposal are clearly framed with regard to the legal phenomenon of the corporate group. This may seem surprising, since the focus of the instrument is on small and medium sized enterprises (SME). One has to consider, however, in this respect that the notion of a corporate group is not restricted to large multinational entities. As Gower E Davies correctly point out, even relatively modest businesses often operate through groups of companies. ${ }^{3}$ Without delving into details on definitions, ${ }^{4}$ the basic

1 Proposal for a directive of the European Parliament and of the Council on single-member private limited liability companies, $\operatorname{COM}(2014) 212$ final, 9.4.2014, p.2, available at http://ec.europa.eu/justice/civil/company-law/index_en.htm.

2 For a first overview see: H.E. Boschma, 'Het plan voor een nieuwe EU-richtlijn vorr de eenpersoonsvennottschap', [2014] Ondernemingsrecht, 144; Benoit Lecourt, 'La nouvelle société unipersonnelle à responsabilité limitée proposée par la Commission européenne', [2014] Revue des Sociétés, 699; Catarina Serra, 'Societas Unius Personae (SUP) um Golem na União Europeia?', [2014] Direito das Sociedades em Revista, 127; Christoph Teichmann/Andrea Fröhlich, 'Societas Unius Personae (SUP) - Facilitating CrossBorder Establishment', [2014] Maastricht Journal of European and Comparative Law (MJ) 536; a comprehensive account on the German debate will soon be published by M Lutter/J Koch (editors), Societas Unius Personae (SUP), (Berlin, 2015).

3 Gower \& Davies, 'Principles of Modern Company Law', 9th edition (London, 2012), p. 244 (9-17). Federico Pernazza, 'International Encyclopaedia of Laws - Italy' (Alphen aan den Rijn 2009), p. 239, also mentions that groups of companies are a frequent phenomenon among small and medium-sized enterprises in Italy.

4 The necessity to legally define the group comes into play, for instance, in accounting law where the companies belonging to the same group have to set up consolidated accounts 
structure of the group consists of several companies linked to each other, typically by a majority shareholding of one company in the other. A group of companies comes into existence when company A decides to incorporate or to acquire company $\mathrm{B}$, the acquiring company $\mathrm{A}$ thereby becoming the 'parent', the acquired company B the 'subsidiary'.

If we take as a definition that a group exists if two or more limited-liability companies are belonging to the same shareholder, the group is the rule and not the exception. This is even more the case in a cross-border environment. The businesses that are engaged in cross-border activities usually are organized as limited-liability companies under their domestic law. This has been stimulated by recent reforms in many EU Member States aiming to reduce obstacles for creating limited-liability companies, in particular by reducing or abolishing minimum capital requirements. ${ }^{5}$ It is therefore likely that most of the SMEs, in particular those who may consider expanding in cross-border business, are run by limited-liability companies under their domestic company law. When considering a cross-border establishment they may either create a local branch or incorporate a limited-liability company under the domestic law of the host state. As will be further elaborated below, the second option, incorporating a new company in the host state, has many practical advantages and results in the formation of a corporate group. The general approach of the EU Commission therefore deserves support. If EU law wants to stimulate cross-border activities of SMEs it should facilitate the establishment and management of subsidiaries.

A similar approach has already been chosen for introducing a European Private Company (EPC). ${ }^{6}$ The EPC, however, would have had a broader scope of application. It was designed as a supranational legal entity for one or more shareholders. And it allowed for drafting articles of association which could have been used for an EPC incorporated in any EU Member State. ${ }^{7}$ It would have offered a wider range of practical usage. But one of the aspects which

(see Art. 2 sec. 11, Directive 2013/34/EU: “'group’ means a parent undertaking and all its subsidiary undertakings").

5 For an overview, see Carl-Heinz Witt, 'Modernisierung der Gesellschaftsrechte in Europa', [2009] Zeitschrift für Unternehmens- und Gesellschaftsrecht (ZGR) 872; more recently also Mette Neville and Karsten Engsig Sørensen, 'Promoting Entrepreneurship The New Company Law Agenda', [2014] European Business Organization Review (EBOR) 545.

$6 \operatorname{COM}(2008) 396 / 3$, available at http://www.europeanprivatecompany.eu (under "legal texts").

7 Christian Schubel, 'Die Binnenorganisation der Societas Privata Europaea' in: P. Hommelhoff/C. Schubel/C. Teichmann (editors), Societas Privata Europaea (SPE) - die europäische Kapitalgesellschaft für mittelständische Unternehmen, (Baden-Baden, 2014) 83106. Christoph Teichmann, 'The Law Applicable to the European Private Company' in: 
were also raised in favor of the EPC was the setting-up of subsidiaries and the creation of standardized group structures. ${ }^{8}$ Based on Article 352 of the Treaty on the Functioning of the European Union (TFEU), the EPC required unanimous consent of the Member States, but Germany rejected the proposal for reasons of protecting German co-determination. ${ }^{9}$ Meanwhile, Germany has regretted its destruction of the EPC proposal and is trying to revive it. ${ }^{10} \mathrm{But}$ even if the SUP Proposal follows a different approach (harmonization instead of supranational legal entity, single-member company instead of being available for more shareholders), its basic idea stems from the same practical problems: SMEs are not active in cross-border business and one reason for that may be the disproportionate cost of incorporating and managing subsidiaries under a foreign legal system.

\section{Facilitating the Establishment of Subsidiaries}

The SUP Proposal clearly addresses this issue by highlighting the fact that in a cross-border context there are good reasons for creating a new company instead of a simple branch. ${ }^{11}$ Businesses often establish subsidiaries in other Member States because they want to offer customers the security of dealing with a national company of their own legal system, whereas at the same time they can sell their products and offer their services with the brand and reputation of the parent company. ${ }^{12}$ Currently, the costs for establishing a company abroad involve the costs of meeting legal and administrative requirements which are different to what businesses are accustomed to in their state of origin, which leads to additional costs for legal advice and translation. Those costs are particularly high for groups of companies since any parent company is faced with different requirements for each country in which it wishes to establish a subsidiary.

H Hirte/C Teichmann (editors), The European Private Company - Societas Privata Europaea (SPE), (Berlin, 2013) 71, 82.

8 Robert Drury, 'Why Do we Need The European Private Company (Societas Privata Europaea)?', in H Hirte/C Teichmann (editors), The European Private Company Societas Privata Europaea (SPE), (Berlin, 2013), 33, 37.

9 On this issue see Rüdiger Krause, 'Co-Determination by Workers under the proposed European Private Company (SPE)', in: H Hirte/C Teichmann (editors), The European Private Company - Societas Privata Europaea (SPE), (Berlin, 2013) 375.

10 The EPC project is even mentioned in the coalition agreement of the current German government (see Peter Hommelhoff/Christoph Teichmann, 'Die Wiederbelebung der SPE', [2014] GmbH-Rundschau (GmbHR) 177) see also Stephan Harbart in this issue p. 230, 234.

11 For a detailed analysis of this argument see below III.2.b).

$12 \operatorname{COM}(2014) 212$ final, 9. 4.2014, p. 2. 
Business associations have long been pointing out that, while many SMEs sell their products abroad, they may not be big enough to maintain their own legal departments or constantly employ the services of an international law firm..$^{13}$ They learn by bitter experience that foreign establishments are disproportionately expensive. For company law issues alone, the formation of each foreign subsidiary may cost many thousands of Euros - for the choice of the appropriate legal form, the formation formalities and the drafting of the articles of association. ${ }^{14}$ Since the law of private companies is not harmonized, the experience gained in country A is useless in country B. The same advisory costs for the same issues arise in the course of the formation of each new subsidiary.

In this respect the debate on the European Private Company has delivered a lot of insight into the day-to-day obstacles of cross-border establishment. Companies having already incorporated subsidiaries in other Member States report that "on average it will take two to four months (sometimes up to six months) until all prerequisites for the foundation have been met. Only after the necessary cooperation with lawyers, notaries, public authorities and the determination of a location have been sorted out, can the company be incorporated." ${ }^{15}$ It is true that issues such as finding a location will not be solved by EU law. But other obstacles can be reduced by harmonizing company law issues and the businesses concerned await such developments with bated breath. They could expect significant simplification of their task to create subsidiaries abroad if there were comparable company law rules in every Member State. ${ }^{16}$ The SUP Proposal therefore aims at facilitating cross-border activities of companies, by providing a national company law form that will follow the same rules in all Member States. ${ }^{17}$

\section{Facilitating the Management of Subsidiaries}

But SMEs face disproportional burdens not only when forming a subsidiary but even more so in ongoing operation. Company law developments in each Member State must be monitored and foreign legal advisors consulted for

13 See Kuck/Weiss, Der Konzern 2007, p. 498 (499) as to the reasoning of the European Parliament when advocating the SPE proposal. Cf. also statements of the German Chambers of Industry and Commerce (DIHK) and the German Business Federation and German Employers' Association (BDI and BDA) on the SPE draft, available at http://www.europeanprivatecompany.eu (under "working papers").

14 Cf. The study of the law firm Baker \& McKenzie, available at http://www.europeanprivatecompany.eu (under "working papers").

15 Kristina Schunk of Schunk GmbH \& Co. KG in a presentation held before the Legal Affairs Committee of the European Parliament, [2006] European Company Law, 275.

16 Kristina Schunk, Ibid., p. 275.

$17 \operatorname{COM}(2014) 212$ final, 9. 4.2014, p. 3. 
every measure required by company law (shareholders' resolutions, distributions to shareholders, appointment and removal of management bodies). They are left with the choice of either taking a legal "shot in the dark" or not forming a foreign company at all. Any benefit from competition between jurisdictions is only discernible if the intended project has a certain dimension due to the scale of which the costs are rapidly recovered. Those obstacles are particularly burdensome for an SME parent. ${ }^{18}$

The ambition of the SUP Proposal therefore is not limited to the first step, which is the incorporation of the subsidiary. It also encompasses the later operation of the subsidiary: ${ }^{19}$ The SUP shall be formed and shall operate in compliance with harmonized rules in all Member States; and it shall diminish set-up and operational costs for the subsidiary. This second aspect, reducing operational costs by harmonizing national law, is particularly achieved by common rules on the relationship between the single shareholder and the management organ: The shareholder appoints the directors (Art. $21 \mathrm{sec} .2$ (e) SUP Proposal); he may remove them at any time whereby the director will be immediately deprived of the authority and power to act on behalf of the SUP (Art. 22 sec. 5 SUP Proposal). Moreover, the shareholder has the right to give instructions to the directors (Art. 21 SUP Proposal).

Once more, the discussion on the SPE can be referred to when the usefulness of these rules shall be assessed. A former fellow student of the author worked for many years for a medium sized company in southern Germany. ${ }^{20} \mathrm{He}$ was the sole lawyer employed by the firm (which in itself is an exception, as many SMEs have no in-house lawyer at all). The company he was working for had been founded in 1993. Ten years later, the company already employed more than 80 people. The products could successfully be marketed in many different countries. The company achieved $42 \%$ of its turnover abroad. This had led to a structure with a private company in Germany and 23 foreign subsidiaries. This is, at least from anecdotal evidence, by no means an exceptional case. It is typical for the exportoriented German "Mittelstand", where subsidiaries in other countries are usually created for service and distribution purposes, but it can be considered as a general blueprint for the strategy of SMEs who want to expand and to do business in other countries. Even countries whoseSMEs have alowerlevel of cross-border activity should consider that facilitating the creation of cross-border subsidiaries could help their businesses to make better use of the Common Market. ${ }^{21}$

18 Ibid., p. 2.

19 Ibid., p. 3.

20 This paradigmatic but nonetheless real case has already been described by the author in Recht der Internationalen Wirtschaft (RIW) 2010, 120 et seq.

21 This is one of the reasons why authors from the 'new' member states are in favor of introducing company law rules facilitating the creation of subsidiaries: Krzysztof 
The problem which SMEs are regularly facing derives from the fact that they have no in-house knowledge whatsoever on foreign legal systems. It is surprising that they do not complain about this fact, a circumstance most likely attributable to their 'hands on' approach of doing business first and thinking about possible legal consequences afterwards. What is more, their managers are seldom lawyers and they are simply unaware of legal risks in other countries. ${ }^{22}$ In the above mentioned case the managing director of the German parent at a certain point became aware of the diversity in his group. But the lawyer couldn't help him. Within his SME-group the following European jurisdictions were concerned: Austria, the Czech Republic, Denmark, France, Greece, Italy, the Netherlands, Poland, Portugal, Rumania, Slovakia, Spain and the UK. It is, however, well-known that in the European internal market the law on private companies, such as the Gesellschaft mit beschränkter Haftung in Germany, is still an area of national law practically untouched by legal harmonization. The commercially minded, uncontroversial requirement of group governance that all subsidiaries be equipped with the same articles of association is therefore a legal impossibility which the in-house lawyer soon realized. Ever since he has been a strong advocate of the proposal to introduce a European Private Company. ${ }^{23}$ Even if the EPC would have been the best solution to solve the problem, the SUP might be worth supporting as the second-best solution.

\section{The two Perspectives on Group Law}

When taking a closer look at the group-related aspects of the SUP Proposal a remarkable shift of perspective becomes apparent: The traditional view according to which groups of companies are a potential danger to the interests of minority shareholders and creditors (see below 1) is retreating. Instead, EU law adopts the 'enabling law' perspective in facilitating the establishment and functioning of groups in a cross-border context (see below 2). This can be

Oplustil, ‘Ausgestaltung und Einsatzmöglichkeiten der Europäischen Privatgesellschaft aus Sicht der in den neuen Mitgliedstaaten ansässigen kleinen und mittleren Unternehmen (KMU)', in: C Teichmann (editor), Europa und der Mittelstand (Baden-Baden, 2010), 109, Arkadiusz Radwan and others, 'European Private Company - A View from the New Europe', [2007] EBLR, 772.

22 In confidential interviews, even legal services of large companies sometimes admit that they simply expect foreign legal systems to be similar to their own and, consequently, apply the same concepts of group governance they have elaborated for the national group.

23 How the EPC could have helped to solve the problem is elaborated by Christoph Teichmann, 'Die Societas Privata Europaea (SPE) als ausländische Tochtergesellschaft' [2010] Recht der Internationalen Wirtschaft (RIW), 120. 
explained by the fact that the protective function nowadays is left to the diversity of national law, which is one reason for the difficulties of organizing corporate groups in the single market (see below 3 ).

\section{Protective Function of Group Law}

\section{a. The Traditional Approach}

Corporate groups are traditionally considered as being potentially dangerous. Business decisions of the parent company may be taken on the basis of maximizing the wealth of the group as a whole - or even exclusively the wealth of the parent - rather than in the interest of a particular subsidiary. ${ }^{24}$ By its influential power as single or major shareholder the parent may impose its strategy on the subsidiaries without taking account of their own interests. Hence, the basic assumption of company law, that each company as a separate legal entity is acting in its own interest, is put at stake. At first sight, this notion of the interest of the company may seem artificial. But it is, as a matter of fact, reflecting the interests of minority shareholders and creditors. The question as to whether and to what extent minority shareholders and creditors of the subsidiary need to be protected leads to the core of group law discussion. ${ }^{25}$ Their investment in the company is based on the assumption that the organs of the company will strive to increase the welfare of the company as such and will not allow outsiders to influence the business policy in a way which is detrimental to the company. The duties of the company's directors are shaped accordingly. The subsidiary's directors face liability for breach of duty if they follow instructions from the parent which are not in the interest of the subsidiary.

\section{b. National Solutions}

Some countries, such as Germany, came to the conclusion that groups of companies require a particular legal framework in order to balance the inter-

24 Cf. among others: José A. Engrácia Antunes, 'The Law of Corporate Groups in Portugal', ILF Working Paper 084, 2008, available at http://www.ilf-frankfurt.de, p. 6. Volker Emmerich in: V. Emmerich/M. Habersack (editors), 'Aktien- und GmbH-Konzernrecht', 7th ed. (Munich 2013), $\$ 15$ marg. No. 6; Gower \& Davies, 'Principles of Modern Company Law', $9^{\text {th }}$ edition (London, 2012), p. 244 (9-17); Federico Pernazza, 'International Encyclopaedia of Laws - Italy' (Alphen aan den Rijn 2009), p. 239.

25 This focus of the problem seems to be common ground for the European discussion, cf. Forum Europaeum Corporate Group Law, 'Corporate group Law for Europe', [2000] European Business Organization Law Review (EBOR), 165, 170. 
ests of the parent company and those of the subsidiaries. ${ }^{26}$ This approach is based on the assumption that corporate groups are, on the one hand, a legitimate way to organize a business. The creation of subsidiaries allows a separation of risks attached to a particular business activity. This is a legitimate intention since company law as such is basically a tool to mitigate risks by making use of limited liability. ${ }^{27}$ Limited liability, on the other hand, has its downsides which may particularly materialize within a group of companies. Shielding the majority shareholder against personal liability could be abused by shifting all the risks to minority shareholders and/or creditors while the majority shareholder takes all the benefits. ${ }^{28}$ Therefore, the German Act on public companies (Aktiengesetz) only allows the parent to give instructions to the subsidiary if the two companies entered into a so-called domination agreement and thereby the parent took the responsibility to cover the losses of the subsidiary and to offer the minority shareholders a sell-out right. ${ }^{29}$ In all other cases the parent has to acknowledge the proper interest of the subsidiary. It has to be noted, however, that these provisions do not apply to the private company where the shareholder is always entitled to give instructions. The private company therefore accounts for the great majority of subsidiaries in German groups.

Other countries, like the United Kingdom, did not feel the need to establish particular rules for corporate groups..$^{30}$ They act on the basic assumption that each company is a separate legal entity and that the major or even the single shareholder can benefit from the privilege of limited liability which will only

26 The German concept of group law has influenced some other European jurisdictions like Portugal, Slowenia, Croatia, Hungary and the Czech republic (as to the countries from Middle and Eastern Europe see the country reports collected by M Winner (editor), 'Haftungsrisiken für die Konzernmutter in Mittel- und Osteuropa' (Wien 2013). An interesting mixture of different systems can be found in the recent reform on group law in Italy; see Renato Santagata, 'Autonomia private e formazione dei gruppi nelle società di capitali', in: P. Abbadessa/G.B. Portale (editors), Il nuovo diritto delle società, Lilber amicorum Gian Franco Campobasso (Rome 2006), 797.

27 Gregor Bachmann/Horst Eidenmüller/Andreas Engert/Holger Fleischer/Wolfgang Schön, 'Regulating the Closed Corporation (de Gruyter, 2014) 124 et seq.

28 See the explanatory memorandum of the German legislator when introducing provisions on groups in the Act on Public Companies (Aktiengesetz) of 1965: B Kropff (editor), Textausgabe des Aktiengesetzes mit Gesetzesbegründung (Düsseldorf 1965), p. 373.

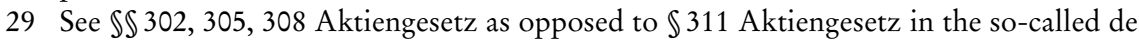
facto group. For an account on German group law see Adriaan Dorresteijn/Tiago Monteiro/Christoph Teichmann/Erik Werlauff, 'European Corporate Law', 2 ${ }^{\text {nd }}$ ed. (Alphen aan den Rijn 2009), 284.

30 Gower \& Davies, 'Principles of Modern Company Law', 9th ed. (London, 2012), p. 244 (9-17). Brenda Hannigan, 'Company Law', 3'rd ed. (Oxford, 2012), p. 54 (3-35 until 3-43). 
in exceptional cases be disregarded. ${ }^{31}$ This is balanced, however, by the duties and responsibilities of the directors to act in the interest of the company. These duties may in some cases be applied to the parent company acting as a so-called 'shadow director' of the subsidiary. ${ }^{32}$ An intermediary position is taken by countries like France who, on the one hand, also apply general company law rules to corporate groups but who, on the other hand, acknowledge that these rules need to be adapted to the specific situation of a corporate group. The famous 'Rozenblum-case' created a flexible test for corporate groups setting out the conditions under which a parent may impose an overall group policy to the subsidiaries without having to face liability for being in breach of duty against the interests of the subsidiary. ${ }^{33}$

\section{c. European Attempts to Regulate the Group}

On the European level the basic view that in a corporate group the minority shareholders and creditors of the subsidiary are exposed to particular risks seems to be generally accepted. ${ }^{34}$ Consequently, European attempts to regulate the corporate group so far followed the protective approach. The draft for a ninth company law directive on groups was influenced by - and did in fact even go beyond - German company law. ${ }^{35}$ It did not, however, even find sufficient approval within the European Commission and "seems to have sunk without trace". ${ }^{36}$ The problem remained. Over time many expert groups reminded the European legislator that cross-border corporate groups are the predominant structure of doing business in the internal market and that this

31 Gower \& Davies (above no. 30), p. 218 (8-8). Hannigan (above no. 30), p. 54 (3-35).

32 Gower \& Davies (above no. 30), p. 245 (9-18). Hannigan (above no. 30), p. 54 (3-50).

33 Cour de Cassation - Cass. crim 4.2.1985, JCP/E 1985, II, 14614 followed by Cour de Cassation - Cass. com. 12.11.1973, Bull. civ. IV Nr. 322. For an account of the case law in the 20 years after Rozenblum see Marie-Emma Boursier, 'Le fait justificatif de groupe de sociétés dans l'abus de biens sociaux: entre efficacité et clandestinité', [2005] Revue des sociétés, 273.

34 High Level Group of Company Law Experts, 'Report on a modern regulatory framework for company law in Europe’, 4 november 2002, p. 94; Forum Europaeum Corporate Group Law, 'Corporate group Law for Europe', [2000] EBOR, 165, 173.

35 Draft Proposal for a Ninth Council Directive pursuant to Article 54(3)(g) of the EEC Treaty relating to links between undertakings and in particular on groups. See Erik Werlauff, 'EC Company Law', 2nd edition (Copenhagen 2003) 89. The German version of the draft proposal is reprinted in Marcus Lutter, 'Europäisches Unternehmensrecht', $4^{\text {th }}$ ed. (Berlin, 1996), p. $244 \mathrm{ff}$. For harsh criticism see Steven M. Schneebaum, 'The Company Law Harmonization Program of the European Community', [1982] 14 Law \& Policy in International Business, 293, 317.

36 Vanessa Edwards, 'EC Company Law', (Oxford 1999), p. 391 
fact may require more attention. ${ }^{37}$ In the late 1990s an international academic group (Forum Europaeum Corporate Group Law) tried to reinvigorate the corporate group discussion. ${ }^{38}$ The successive Forum Europaeum on Corporate Groups only recently formulated basic principles which could help to introduce the group aspect in the internal market. ${ }^{39}$ The European Commission in its Action Plan of 2012 acknowledged the interest in "well-targeted EU initiatives on groups of companies". ${ }^{40}$

\section{Enabling Function of Group Law}

In the recent discussion on group law the protective perspective has increasingly faded and the enabling function of group law has seen the light. ${ }^{41}$ Modern doctrine supports the function of company law as 'enabling law'. ${ }^{42}$ This aspect of company law is described by Cheffins as follows: "Most often, permissive rules legitimize arrangements that otherwise might not be valid." 43 In a crossborder context this could also apply to group law. The fact that there are no European rules on groups means that cross-border groups have to tackle many different legal systems, all of which take the view that subsidiaries need to be protected against the influence of the parent and that subsidiaries need to be managed in the interest of the subsidiary. The assumption that the subsidiary is a separate legal entity having an interest in its own may be correct from a legal

37 Reflection Group on the Future of EU Company Law, Report, 5 April 2011, p. 59 et seq. High Level Group of Company Law Experts, 'Report on a modern regulatory framework for company law in Europe’, 4 November 2002, p. 94; Forum Europaeum Corporate Group Law, 'Corporate group Law for Europe’, [2000] EBOR, 165, 167: “Corporate groups are a fact of life”.

38 Forum Europaeum Corporate Group Law, 'Corporate group Law for Europe', [2000] EBOR 165.

39 See the publication of this proposal in this ECFR issue.

$40 \operatorname{COM}(2012) 740$ final, p. 14, available at http://ec.europa.eu/justice/civil/companylaw.

41 For further analysis see Christoph Teichmann, 'Europäisches Konzernrecht: Vom Schutzrecht zum Enabling Law', [2013] Die Aktiengesellschaft, 184, as well as MarcPhilippe Weller/Johanna Bauer, 'Europäisches Konzernrecht: vom Gläubigerschutz zur Konzernleitungsbefugnis via Societas Unius Personae’, [2015] Zeitschrift für Europäisches Privatrecht (ZEuP), 6.

42 See Gregor Bachmann/Horst Eidenmüller/Andreas Engert/Holger Fleischer/Wolfgang Schön, 'Regulating the Closed Corporation (de Gruyter, 2014) 130; Brian R. Cheffins, 'Company Law' (Oxford 1997), p. 218 and 250. Regarding in particular the enabling function of group law see Peter Hommelhoff, 'Förder- und Schutzrecht für den faktischen GmbH-Konzern', [2012] Zeitschrift für Unternehmens- und Gesellschaftsrecht (ZGR) 535 .

43 Cheffins (above no. 42), p. 249. 
perspective, but it is not from an economic perspective. ${ }^{44}$ In reality the legally independent companies are economically integrated in the framework of a group policy and are subject to instructions or general guidelines from the parent company.

For large groups, like the Italian Pirelli group, the development of a coherent group strategy is a matter of diligent group management. ${ }^{45}$ They simply have no other choice if they want to avoid being negligent as directors of the parent. This need has become more and more important since public authorities strictly enforce the responsibility to establish efficient compliance procedures in corporate groups. If the parent of a cross-border group were not looking after its subsidiaries and not trying to influence them, the directors of the parent would face personal responsibility for any misbehavior of the subsidiary's organs or employees. ${ }^{46}$ In Germany, for instance, a board member of Siemens AG was held personally liable for damages caused to the company by corruption practices in foreign subsidiaries - even though it was clearly established that the board member was not personally involved in these practices and had no knowledge of them. But the court argued that he could have known and could have done something to avoid these practices. ${ }^{47}$ The courts thereby assume that the parent has the power to influence the subsidiaries, which is, however, not certain at all given the different approaches of national company law to the group phenomenon. It would therefore be extremely helpful for corporate groups to have a number of basic, uniform principles regarding the most significant profiles of group governance at the EU level. ${ }^{48}$

44 Pierre-Henri Conac, 'Director's Duties in Groups of Companies - Legalizing the Interest of the Group at the European Level', [2013] ECFR, 194, 195.

45 See the article by Francesco Chiappetta (Pirelli Group General Counsel) and Umberto Tombari, 'Perspectives on Group Corporate Governance and European Company Law', [2012] ECFR, 261, 265.

46 Out of numerous articles in Germany on this issue, the following directly address the group-related aspect: Eike Bicker, 'Compliance - organisatorische Umsetzung im Konzern, [2012] Die Aktiengesellschaft (AG), 542; Nikolaus Bunting, 'Konzernweite Compliance - Pflicht oder Kür?‘, [2012] Zeitschrift für Wirtschaftsrecht (ZIP), 1542; Uwe H. Schneider/Sven H. Schneider, 'Konzern-Compliance als Aufgabe der Konzernleitung', [2007] ZIP, 2061. Dirk A. Verse, 'Compliance im Konzern' [2011] Zeitschrift für das gesamte Handelsrecht und Wirtschaftsrecht (ZHR), 401. Daniela Weber-Rey/Evgenia Gissing, 'Gruppen - Governance - das Gruppeninteresse als Teil des internen Governance-Systems im Finanzsektor', [2014] AG 884. See also the book by Charlotte E. Grundmeier, 'Rechtspflicht zur Compliance im Konzern' (Cologne 2011).

47 Landgericht München, judgment of 10 December 2013, [2014] ZIP, 570.

48 Francesco Chiappetta (Pirelli Group General Counsel) and Umberto Tombari, 'Perspectives on Group Corporate Governance and European Company Law', [2012] ECFR, 261, 265. 
While the compliance aspect may be of less practical importance for SMEs, they have a strong interest to use simple tools for organizing a cross-border structure of small subsidiaries for distributing their products and rendering service to the client. Their practical needs will be further elaborated below (IV.1).

\section{Cross-border Business Structures and EU Freedom of Establishment}

In the political discussion on possible EU rules on corporate groups in general and on the SUP Proposal in particular there is a strong opposition against the European Union taking legislative action. Some authors assume that there is no practical need for European secondary law, others raise doubts as to whether the EU has competence to regulate these aspects at all. In order to assess these arguments, the European freedom of establishment plays a pivotal role. The discussion widely ignores that corporate groups - at least in a cross-border context - are protected by the European freedom of establishment (see below 1). It is true that businesses can also establish cross-border branches but this is often, from a practical point of view, only the second-best solution (see below 2). Hence, there is reasonable justification to enact secondary law in order to facilitate the creation and management of subsidiaries (see below 3).

\section{Cross-Border Groups in the Framework of the TFEU}

\section{a. The Scope of Articles 49 and 54 TFEU}

Cross-border establishment of businesses is a key element of the European internal market. Therefore, the freedom of establishment as one of the fundamental freedoms of the TFEU allows businesses to set up establishments in other Member States without being restricted by national measures. 'Establishment' in the sense of the Treaty means the actual pursuit of an economic activity through a fixed establishment in another Member State for an indefinite period..$^{49}$ This freedom to cross-border establishment is granted to natural persons (Article 49 TFEU) and companies alike (Article 54 TFEU).

Article 49 (1) TFEU further elaborates the different means of cross-border establishment. Naturals of any Member State may set up agencies, branches or subsidiaries. The 'subsidiary' is expressly mentioned as one possibility to

49 Court of Justice, judgment of 25 July 1991, C-221/89 (Factortame), marg. no. 20; Court of Justice, judgment of 12 July 2012, C-378/10 (Vale), marg. no. 34. 
establish in another Member State. This right is also granted to companies or firms formed in accordance with the law of a Member State (Article 54 TFEU). When a company formed under the laws of one Member State incorporates a subsidiary in another Member State, a group of companies in the legal sense comes into existence: Two companies as separate legal entities which are legally and economically linked to each other by a shareholding of one company in the other. It follows that the creation of a cross-border group of companies is protected by the EU Treaty. ${ }^{50}$

\section{b. Equal Protection for Branches and Subsidiaries}

Even though there are different ways to set up an establishment in another Member State (like branches, agencies or subsidiaries), there is no legal preference for one over the other. Every possible means of establishment is protected by Articles 49 and 54 TFEU uniformly. ${ }^{51}$ Member States must not discriminate or restrict the establishment of either a branch or a subsidiary. The equal value and equal level of protection for these different types of establishment has been confirmed by the Court of Justice in the Case Commission/Republic of France. In this case a provision in French law which was discriminating against branches of foreign companies was under consideration. The Commission claimed that this discrimination was incompatible with European law. France argued that subsidiaries of foreign companies were treated the same way as subsidiaries of French companies. A foreign company could well have avoided the disadvantageous treatment of its branch by establishing a French subsidiary instead. The Court of Justice, however, stated the equal value of the different types of establishment and the freedom of choice amongst them: Primary law (Article 52 TEU at the time of the judgment, Article 49 TFEU today) "expressly leaves traders free to choose the appropriate legal form in which to pursue their activities in another Member State". ${ }^{52}$ That freedom of choice must not be limited by legal provisions in the host Member State..$^{53}$ This twofold approach of

50 For further analysis see Wolfgang Schön, 'Der Anspruch auf Haftungsbeschränkung im Europäischen Gesellschaftsrecht', in: B Erle/W Goette/D Kleindiek and others (editors), Festschrift für Peter Hommelhoff (Cologne, 2012), p. 1037, 1051, and by Christoph Teichmann, 'Konzernrecht und Niederlassungsfreiheit', [2014] Zeitschrift für Unternehmens- und Gesellschaftsrecht (ZGR), 45, 66.

51 Ulrich Forsthoff in: Grabitz/Hilf/Nettesheim, 'Das Recht der Europäischen Union', 2014, Art. 49 AEUV marg. no. 64.

52 Court of Justice, judgment of 28 January 1986, case 270/83 (Commission/French Republic), marg. no. 22.

53 Ibid. This judgment has later been confirmed by Court of Justice, judgment of 23 February 2006, C-253/03 (CLT-UFA SA), marg. no. 14. 
primary law is also to be taken into acount when harmonization measures are at stake: Legal acts for attaining freedom of establishment (Art. 50 TFEU) shall promote the establishment of branches and of subsidiaries alike.

\section{The Choice between Branch and Subsidiary}

\section{a. The Possibility to use National Company Forms for cross-border Establishment}

The SUP Proposal is based on the assumption that companies find it costly and difficult to be active across borders. ${ }^{54}$ This argument focuses mainly on the act of establishing a foreign company. Establishing a company abroad involves the cost of meeting legal and administrative requirements in other countries, which differ frequently from what companies are used to in their own countries..$^{55}$ Hence, the overall objective of the SUP Proposal consists in making it easier for potential company founders, and in particular for SMEs, to set up companies abroad. ${ }^{56}$

Critics argue that there is no need to facilitate the creation of subsidiaries since companies may as well establish branches. ${ }^{57}$ It has been shown in the previous paragraph that this argument is incompatible with primary law, since one means of establishment shall not be played off against the other. But one may nevertheless raise the question whether there is actually a need for secondary legislation in the area of company law if the needs of businesses are fully met by the existing legal environment. In this respect some authors refer to the possibility to first set up legal entities in a familiar legal environment and then use them for establishing branches. Under the existing freedom of establishment a business could incorporate one or more companies under its domestic law and then use them as 'letterbox-companies' by setting up their headquarters in other Member States. ${ }^{58}$

54 Proposal for a directive of the European Parliament and of the Council on single-member private limited liability companies, $\operatorname{COM}(2014) 212$ final, 9.4.2014, p. 2 (the proposal is retrievable at http://ec.europa.eu/justice/civil/company-law/index_en.htm).

55 Ibid., p. 2.

56 Ibid., p. 3.

57 Jens Bormann, 'Die SUP aus Sicht des nationalen Rechtssystems', in M Lutter/J Koch (editors), Societas Unius Personae (SUP), (Berlin, 2015), p. 23, 25. The same argument had been raised against the Proposal of a European Private Company, see, for instance, Joan Bloemarts, Presentation held before the Committee on Legal Affairs of the European Parliament, [2006] European Company Law, 265.

58 Ibid. 
Thanks to the well-known judgements on the freedom of establishment ${ }^{59}$, a national legal form once selected can be used throughout Europe. Under the European freedom of establishment, an English private limited company, for instance, may conduct its main business not only in London, but also in Berlin or Warsaw. Other Member States would have to accept the applicability of English company law to such legal entities. ${ }^{60}$ An English company which wants to create subsidiaries for doing business abroad could create several British private companies and scatter them around all over Europe, i.e. establish their head offices in different EU Member States thereby creating a crossborder network of subsidiaries all of them being governed by English law.

This view has been somewhat qualified by the Cartesio judgement of the Court of Justice. Art. 49 TFEU does not give a company the right to transfer its management centre abroad and at the same time retain its character as a company of its state of formation. ${ }^{61}$ This restriction, however, has effect only in those states which do not wish to permit their companies to transfer their management centres abroad. The English limited can continue to be used abroad because this is permitted by English law. Germany, too, in the amendment to the Act on limited liability companies (GmbH-Gesetz) on 1 November 2008, decided to permit not only private companies $(\mathrm{GmbH})$ but also public companies (Aktiengesellschaft) to transfer their management centres abroad. ${ }^{62}$ A German business could therefore register several GmbHs in Germany, each of which could operate in another Member State - continuing to be

59 Cf. leading judgements Centros (Rs. C-212/97), Überseering (Rs. C-208/00), Inspire Art (Rs. C-167/01).

60 German courts (who traditionally applied the real seat theory) have drawn the consequence from the above mentioned European case law that the incorporation theory is applicable to companies formed in EU Member States: Bundesgerichtshof (BGH), [2005] Neue Juristische Wochenschrift (NJW), p. 1648 ff. (for the English limited); likewise for companies from the EEA, namely, Liechtenstein (BGH NJW 2005, p. 3351 f.); the same applies by international Treaty to US companies (BGH Betriebs-Berater (BB) 2004, p. 1868 f.). For more references see country report on Germany by Christoph Teichmann, [2006] European Company Law, 27.

61 Court of Justice, judgment of 16 December 2008, C-210/06 (Cartesio), marg. no. 110.

$62 \rrbracket 4 \mathrm{a}$ GmbHG and $\ 5 \mathrm{AktG}$ as amended. The explanatory memorandum of the legislator expressly emphasises that it was intended to give German companies the opportunity to transfer their management centres abroad while retaining the application of German company law (Begr. RegE zu $\ 4$ a GmbHG, BT-Drs. 16/6140, p. 29). For more on associated international company law issues: Jochen Hoffmann, 'Die stille Bestattung der Sitztheorie durch den Gesetzgeber', [2007] Zeitschrift für Wirtschaftsrecht (ZIP), 1581; Heinz Kußmaul/Lutz Richter/Christoph Ruiner, 'Corporations on the Move, the ECJ off track: Relocation of a Corporation's Effective Place of Management in the EU', [2009] European Company Law (ECL), 246; Rüdiger Werner, 'Das deutsche Internationale Gesellschaftsrecht nach Cartesio und Trabrennbahn', [2009] GmbHRundschau (GmbHR), 191. 
subject to the German GmbH Act, as long as the international private law of the other states concerned follows the incorporation theory. Based on the above mentioned European case law, every EU Member State would have to recognize the legal existence of such German $\mathrm{GmbH}$ and must not restrict its establishment in its own territory.

\section{b. Why Branches are not the Solution}

The fact that it is possible to make use of national private companies with branches all over Europe does not mean that it is commercially advisable to do so. Operating abroad by means of a branch of a national legal form is not an adequate alternative to creating a subsidiary. The registration expense of a branch is almost the same as for a limited-liability company under local law, because the publication obligations of the First Company Law Directive (for companies) ${ }^{63}$ and the Eleventh Council Directive (for their branches) ${ }^{64}$ are almost identical. A recent survey conducted by Becht et al. surprisingly indicates that it may even be more burdensome to register a branch than to incorporate a company. ${ }^{65}$ From a group of ten experts each of them incorporated a UK Limited and attempted to register a branch in their respective home countries. In some countries this procedure took several months and created legal costs amounting to several thousand Euros. Of the ten experiments only five resulted in easy branch registration; two had to be abandoned at an early stage, a further two were abandoned just before the final steps due to cost considerations, one succeeded to registration only after considerable bureaucratic obstacles were surmounted. ${ }^{66}$ This study might serve as a justification for further harmonization in the area of branches, but it definitely does not contribute to recommend the branch as the preferred model for cross-border establishment.

Another argument against the 'branch model' is the unsecure dividing line between the company law in the state of incorporation and the applicable legal rules in the host state. Businesses using a domestic company in order to set up a branch in another Member State have to deal with two legal systems within one company. ${ }^{67}$ Many German businesses, for instance, which used the UK

63 First Council Directive 68/151/EEC, today applicable in a revised version as Directive 2009/101/EC of 16 September 2009, OJ EU, 1 October 2009, L 258/11.

64 Eleventh Council Directive 89/666/EEC.

65 Marco Becht/Luca Enriques/Veronika Korom, 'Centros and the Cost of Branching', in: $\mathrm{M}$ Tison/H de Wulf/C van der Elst/R Steennot (editors), Perspectives in Company Law and Financial Regulation (Cambridge, 2009), 91.

66 Ibid., p. 97, conclusion of the results.

67 See Christoph Teichmann, 'The Downside of being a Letterbox Company', [2012] ECL, 180. 
Limited were quite often unfamiliar with the UK disclosure rules. As a consequence, German courts nowadays have to deal with an increasing number of 'zombie' companies, first incorporated in the United Kingdom, then deleted from the Companies House register due to non-compliance with the applicable disclosure rules, but - in unawareness of deletion - continuing business in Germany under the flag of a UK Limited. This leads to complicated legal issues regarding the ownership of the former Limited's assets and the liability for the debts incurred after deletion of the company. ${ }^{68}$

Another legal problem of the 'branch model' is tax law. National tax law usually attaches tax duties either to the fact that a company is registered within the state's territory or to the fact that the company has a permanent establishment within the state's territory. In the case of a branch, even more if it is in fact the headquarter of a 'letterbox company', the state of registration and the state where the branch is located will both claim the right of taxation - a situation only controllable at great expense and on the basis of bilateral double taxation agreements. ${ }^{69}$

It follows that the branch creates the same or even more legal problems than a subsidiary without being able to offer the advantages of a subsidiary. Usually, business partners and local authorities appreciate the fact that there is a company incorporated in the host state whereas a foreign company form creates distrust. The unspoken question of why a locally registered company was not chosen for business on the local market remains in the air. This assumption is backed by empirical data on the use of the UK Limited in Germany. Whereas German businesspeople at the beginning were enthusiastic about the Limited, incorporation numbers started to fall quite some time before Germany actually introduced the new 'Unternebmergesellschaft (baftungsbeschränkt)' as a simple and cheap alternative to the UK Limited. ${ }^{70}$ Which can best be ex-

68 See the following cases: Oberlandesgericht Nürnberg, [2008] Neue Zeitschrift für Gesellschaftsrecht (NZG) 76; Oberlandesgericht Celle, [2012] Neue Juristische Wochenschrift - Rechtsprechungsreport (NJW-RR), 1065; Oberlandesgericht Hamm, [2014] NZG, 703; Kammergericht Berlin, [2014] NZG, 901.

69 As to double taxation in cross-border circumstances see Tobias Schädle/Maximilian F. Eich, 'Die grenzüberschreitende Sitzaufspaltung der SPE aus Sicht des deutschen Steuerrechts', [2012] Deutsches Steuerrecht (DStR), 2341, 2344, who come to the conclusion that the split of registered office and headquarter is commercially not to be recommended.

70 For a comprehensive empirical analysis see: Wilhelm Niemeier, 'What Kinds of Companies will a "One-Euro-EPC” generate?", in: H Hirte/C Teichmann (editors), The European Private Company - Societas Privata Europaea (SPE), Berlin 2013, 293, 304; Wolf-Georg Ringe, 'Corporate Mobility in the European Union - a Flash in the Pan? An empirical study on the success of lawmaking and regulatory competition', [2013] ECFR, 230, 251, concludes: "The important finding is that the numbers seem to fall way before the German law reform took effect." 
plained by the assumption that a foreign legal entity creates unnecessary costs and complications and that, after all, a national legal entity is always the best way to do business in a particular Member State.

Finally, the special situation of the Member States which have become new members of the community in the past decades should be taken into account. Requiring them to use their own national legal forms by establishing branches in other Member States is equivalent to indirect discrimination against them, since, while the UK Limited and the German GmbH may be known in Europe, the Polish Sp. z o.o., for example, is not. ${ }^{71}$ The citizens of other states have problems with such unfamiliar legal forms even on language grounds alone. The competitive advantage of the UK Limited is likely to be based, to a significant extent, on the widespread knowledge of English among the business community. The fact that elsewhere in Europe there are other company forms which require no minimum capital is virtually unknown among German entrepreneurs, not least because of the language obstacles. Only European rules can establish a 'level playing field'.

\section{EU Competence to Act by Means of a Directive}

\section{a. Attaining Freedom of Establishment}

The scope of the Freedom of Establishment, as granted by Articles 49 and 54 TFEU, also has implications for the EU competence to act by means of directives: According to Article 50 (1) TFEU the European Parliament and the Council shall act by means of directives "in order to attain freedom of establishment". The justification to take action on the European level therefore consists in attaining freedom of establishment which includes branches and subsidiaries alike. Consequently, the fact that businesses could act by means of branches and thereby make use of the freedom of establishment is not admissible as a counter-argument to a directive on creating subsidiaries. Both ways are protected equally under EU primary law and it is the free choice of the businesses whether they want to create a branch or a subsidiary. Hence, both means of establishment can justify legislative action on the Union level.

71 This has already been pointed out in the debate on the European Private Company by several authors: Krzysztof Oplustil, 'Ausgestaltung und Einsatzmöglichkeiten der Europäischen Privatgesellschaft aus Sicht der in den neuen Mitgliedstaaten ansässigen kleinen und mittleren Unternehmen (KMU)', in: C Teichmann (editor), Europa und der Mittelstand (Baden-Baden, 2010), 109, 117; Arkadiusz Radwan, 'European Private Company and the Regulatory Landscape in the EU - An Introductory Note', [2007] European Business Law Review (EBLR), 769, 771. 
The Explanatory Memorandum of the SUP Proposal refers in particular to Article 50 (2) (f) TFEU which specifically mentions the abolition of restrictions as regards the setting up of subsidiaries in the territory of a Member State. ${ }^{72}$ One may question this legal basis by pointing out that an SUP can also be founded by natural persons; one may also ask whether Article $50(2)(\mathrm{g})$ TFEU which generally serves as the legal basis for company law harmonisation might be the better option. ${ }^{73}$ But ultimately, this is not the decisive issue, since these provisions merely set out a non-exhaustive list of measures which can be taken within the general objective of attaining freedom of establishment. ${ }^{74}$ If the Commission comes to the well-founded conclusion that there are particular problems related to the incorporation of subsidiaries it is a legitimate objective to reduce these problems by a directive based on Article 50 TFEU which generally allows for directives in order to attain freedom of establishment. This approach is justified even more by the fact, that there are many practical arguments against using branches, as explained in the previous paragraph, and that many companies therefore are strongly interested in creating subsidiaries in other Member States.

The attainment of freedom of establishment means more than the mere abolishment of restrictions. This becomes apparent when a systematic comparison of Article 49 and 50 TFEU is undertaken. Article 49 TFEU grants freedom of establishment as a fundamental freedom of the Treaty which can be directly invoked by citizens of the EU Member States. This fundamental freedom in the case law of the Court of Justice is interpreted as a prohibition to Member States to unjustified restrictions. National measures liable to hinder or make less attractive the exercise of fundamental freedoms guaranteed by the Treaty must be justified by imperative requirements. ${ }^{75} \mathrm{By}$ applying this test the Court of Justice makes sure that EU citizens and companies have free access to the national markets of other Member States. ${ }^{76}$

$72 \operatorname{COM}(2014) 212$ final, 9. 4. 2014, p. 5.

73 The academic debate as to the legal basis for the SUP Proposal cannot be elaborated in detail, see instead: Corrado Malberti, in this ECFR issue; see also Christoph Teichmann, 'Einsatzmöglichkeiten der Societas Unius Personae (SUP)' in: M Lutter/J Koch (editors), Societas Unius Personae (SUP), (Berlin, 2015), p. 37, 54).

74 This latter interpretation has been confirmed in: Court of Justice, judgment of 4 December 1997, C-97/96 (Daibatsu), marg. no. 21.

75 First established in Court of Justice, judgment 30 november 1995, C-55/94 (Gebhard), marg. no. 37. For later application of this test within the freedom of establishment see Court of Justice, judgment 30 September 2003, C-167/01 (Inspire Art), marg. no. 133.

76 As to the function of the fundamental freedoms to grant free access to the markets of the member states see: Christoph Teichmann, 'Gesellschaftsrecht im System der Niederlassungsfreiheit', [2011] ZGR, 639, 649. For an example in case lase see: Court of Justice, judgment of 21 October 2010, C-81/09 (Idrima Tipou AE) marg. no. 56: ”... the na- 
If the competence to act by means of a directive shall have any additional sense it must be interpreted as a means to further facilitate the use of the freedom of establishment. Even if the difference between the national legal systems obviously is not a restriction as such being incompatible with Article 49 TFEU, it could well be a justification to enact secondary law in order to give businesses the trust that they can rely on comparable standards in every EU Member State. ${ }^{77}$ In this line of thought, the purpose of harmonizing company law is described by Wymeersch as follows: It shall ensure that companies can establish themselves all over the Union, without any handicaps or restrictions due to the cross-border nature of their establishment and at a minimal expense. ${ }^{78}$ Given the fact that the diversity of rules creates considerable cost and legal risks for cross-border group management, the Forum Europaeum Corporate Group Law convincingly concludes that, paradoxically, the non-existence of corporate group law could create or maintain restrictions on market access. ${ }^{79}$

\section{b. Company Law and Other Obstacles}

As the Explanatory Memorandum of the SUP Proposal points out, SMEs still face a number of obstacles when they try to expand their activities across the borders and in practice only a small number of SMEs invest abroad. ${ }^{80}$ It is true, as some authors have observed, that there are many other obstacles which have nothing to do with company law. ${ }^{81}$ Tax law, labor law and national bureaucracy in general create stumbling blocks for those who want to do business in other countries. That is not, however, a reason to deny companies the desired facilitation through company law in which the obstacles are more easily surmounted. The fact that there are also problems in other areas of the law should not restrain the EU from taking company law seriously. ${ }^{82}$ And since the scope

tional measure at issue has a deterrent effect on investors and thereby affects their access to the equity market.”

77 With regard to group law: Laurenz Tholen, 'Europäisches Konzernrecht' (Berlin 2014), p. 193.

78 Eddy Wymeersch, 'Company Law in Europe and European Company Law', in: 1st $^{\text {st }}$ European Jurists Forum 2001 (Baden-Baden 2002), p. 85, 108.

79 Forum Europaeum Corporate Group Law, 'Corporate group Law for Europe', [2000] EBOR, 165, 180/181.

$80 \operatorname{COM}(2014) 212$ final, 9. 4.2014, p. 2.

81 For a recent account of all the steps which need to be taken for establishing a business abroad see Dieter Leuering, 'SUP - Perspektiven für die Praxis' in: M Lutter/J Koch (ed), Societas Unius Personae (SUP), De Gruyter (2015) 87.

82 Arkadiusz Radwan and others, 'European Private Company - A View from the New Europe’, [2007] EBLR, 772, 776. 
of the proposed directive is restricted to company law its usefulness can only be measured by its achievements in the area of company law. It has been elaborated above that the diversity of national company laws is a particular burden for SMEs. ${ }^{83}$ An internal survey of the law firm Baker \& McKenzie even confirmed that the major part of fees for consulting clients who intend to create a subsidiary in a foreign legal environment is related to company law issues. ${ }^{84}$ In this line of thought the Commission for good reasons aims to reduce the complexity which is created by the diversity of national company law legislations when it comes to incorporate and to manage a subsidiary in another EU Member State. ${ }^{85}$

\section{c. Shall Large Companies be Excluded from Using the SUP?}

The argument that theSUP Proposal should particularly be supportive for SMEs has been taken up by statements in the European Parliament claiming that the SUP should exclusively promote micro and small companies (as defined by the EU Accounting Directive) and should not be dedicated to facilitate the creation and functioning of cross-border groups in general. ${ }^{86}$ These political statements reveal a wide-spread mistrust against corporate groups which are frequently conceived to be powerful and potentially abusive organisations. The freedom of establishment, however, is granted irrespective of the size of the company. Even though SMEs may have more difficulties to make use of the freedom of establishment, which makes it a legitimate purpose for a directive, such as the SUP Proposal, to try to facilitate cross-border establishment for SMEs, it is very problematic to restrict such an instrument exclusively to SMEs. The creation of a company in another country, as being guaranteed by the freedom of establishment, is open to anybody and the fact that large companies encounter fewer

83 In this respect a survey of the German Federation of the Engineering Industry should be mentioned which revealed that even SMEs with a workforce as low as 10 employees may depend for up to 80 percent of their turnover on foreign markets. They confirmed that a European legal entity for setting up subsidiaries would of great use for them. The survey is reported by Peter Hommelhoff, 'Die Europäische Privatgesellschaft - Diskussionsstand 2003 und Fortgang', in S Kalss/C Nowotny/M Schauer (editors), Festschrift für Peter Doralt (Wien, 2004), p. 199, 201.

84 The survey carried out by Baker \& McKenzie is available at http://www.europeanprivatecompany.eu (under "working papers").

85 Cf. $\operatorname{COM}(2014) 212$ final, 9. 4.2014, p. 2.

86 Draft Opinion of the Committee on the Internal Market and Consumer Protection (Rapporteur: Marlene Mizzi), 29 January 2015, document 2014/0120(COD), p. 3: “... the directive's scope should be limited to micro and small companies that meet the criteria of the EU accounting Directive (EU) 2013/34 in relation to net turnover and number of employees. Larger undertakings should be excluded, as they do not face the same problems as smaller ones and, also, often use other forms of company law." 
difficulties to create establishments abroad is not a valid reason to discriminate against them in favour of SMEs. Large and small companies are protected uniformly and consistently by the freedom of establishment.

Restricting the scope of the SUP directive to SMEs, would also be counterproductive from an economic perspective. First, small companies making use of such a 'restricted' SUP will have to prove their size before incorporating an SUP. This is a requirement which so far does not exist in any national law. Contrary to the initial intention of the directive, bureaucratic burdens for SMEs will be increased instead of reduced. Second, the link to the size which is defined by number of employees is more than counter-productive. The definition of the Accounting Directive refers to particular thresholds, one criterion being the requirement that small companies may not exceed 50 employees. Hence, the restriction of the SUP to SMEs would lead to the result that smaller companies are punished for creating jobs: Once they cross the threshold of 50 employees they will no longer be allowed to make use of the SUP. Such a result would be economically retrograde and, from a legal point of view, arguably in breach of EU primary law which does not permit such discrimination.

\section{Enabling Provisions for Managing Cross-Border Groups}

\section{Lessons to be Learned from the EPC Debate}

The SUP Proposal to some extent tries to fulfill the same needs and expectations as the EPC Proposal. Whereas the EPC would have had a wider range of application (such as joint-ventures or companies with several shareholders) it was also pointed out that a European company law framework could be helpful for establishing and managing subsidiaries in other Member States. In the case study mentioned above, the managing director of the German company who requested his lawyer to create a common structure in all the foreign subsidiaries saw the following aspects to be the most pressing in order to efficiently govern the group internally: ${ }^{87}$

- In order to represent the company in a foreign market, a local managing director is necessary. The process of appointment and removal must be uncomplicated. A removal must be possible at any time and even without grounds, since ultimately the occupation of the position of managing director is based on trust between the parent company and the managing director concerned. If that trust no longer exists, a rapid removal must be possible.

87 Cf. Christoph Teichmann, 'Die Societas Privata Europaea (SPE) als ausländische Tochtergesellschaft, [2010] RIW, 120, 122. See also M. Ph. Weller/J. Bauer (above no. 41). 
- Internally, the functions and competences must be clearly defined. It is at least desirable that the managing director complies promptly with the instructions from headquarters. In that manner, a coherent cross-border policy can be pursued. Individually, the possibility of flexibly changing the powers of the managing director should be provided. For example, he can, after a certain introductory period, be granted the power to conclude contracts up to a certain limit even without the approval of the parent company.

- Often, the managing director is granted at least a small participation in the subsidiary. This promotes identification with the business. The articles of association must then take account of the fact that there is a minority shareholder in the company, in the form of the managing director, as separate from the parent company. The contract must provide that the managing director cannot assign his interest to a third party, at least not without the consent of the parent company.

- Finally, the parent company requires legal certainty for financial transactions with the subsidiary. Supply agreements and service agreements are often in force within a group of companies. In the EPC legal form, it should be clear whether such transactions are admissible and what company law provisions are applicable to them.

It shall be analyzed below whether and to what extent the SUP Proposal fulfills these needs and expectations.

\section{The SUP Proposal as Enabling Law for Corporate Groups \\ a. National Measures Restricting Wholly Owned Subsidiaries}

The SUP Proposal in many respects represents an enabling law for corporate groups which is to be welcomed. First of all, it is often overlooked that the existing Directive on single-member companies allows Member States to introduce restrictions for cross-border group structures. ${ }^{88}$ Some Member States did or still do make excessive use of this provision. In Poland a limited-liability company is simply denied the right to create a wholly owned subsidiary. ${ }^{89}$ France, for many years, had the same provision and only abolished it last year. ${ }^{90}$ In Belgium a limited-liability company which incorporates a wholly owned

88 Article 2 (2) of Directive 2009/102/EC, OJ EU, 1 October 2009, L 258/20.

89 Art. $151 \rrbracket 2$ kodeks spólek handlowych. The same restriction seems to exist in Romania.

90 Ordonnance $^{\circ}$ 2014-863 v. 31.7. 2014 relative au droit des sociétés, prise en application de l'article 3 de la loi n 2014-1 du 2 janvier 2014 habilitant le Gouvernement à simplifier et sécuriser la vie des entreprises, JORF n0177 v. 2. 8. 2014, S. 12820. 
subsidiary has to bear all the losses of the subsidiary, ${ }^{91}$ which means that the principle of limited liability is ignored in these circumstances. All these provisions arguably are incompatible with the freedom of establishment. ${ }^{92}$ Fortunately, the respective provision of the existing single-member company directive does no longer appear in the SUP Proposal.

\section{b. Appointment and Removal of Directors}

The interest of a single shareholder to be master of his or her own company is confirmed by Articles 21 and 22 SUP Proposal. Article 21 regulates the issues on which the single shareholder is competent to decide. One of these issues is the appointment and removal of directors (Article 21 (2) (e) SUP Proposal). A further provision clarifies that the director, once being removed, can no longer represent the company. Once removed from office, the director will be immediately deprived of the authority and power to act on behalf of the SUP (Article 22 (5) SUP Proposal). This is, of course, essential for the single shareholder. Once he or she has lost confidence in the director and removed him, it must be ensured that the director is no longer acting on behalf of the company against the will of the single shareholder.

Introducing such provisions as a European standard is more useful than it may seem to be at first sight. One may argue that a director in a wholly owned company is always depending on the sympathy of the single shareholder. But when times get rough it is important for the single shareholder to have legal security regarding the possibility to remove the director immediately and to thereby end his authority to represent the subsidiary. This is even more important in a cross-border context. If the single shareholder as the parent is resident in another EU Member State, the director has an advantage over him since the director is a resident in the state where the subsidiary is located and therefore usually will have better knowledge of his or her national company law. For the foreign parent it will cost time and money to assess the legality of a director's purported arguments against the validity of immediate removal under the law of the subsidiary. ${ }^{93}$

91 Art. $213 \$ 2$ Code des sociétés.

92 The fact that the Directive allows for restrictions does not automatically mean that any restriction is admissible. It should still be proportionate in relation to the public interest which it aims to protect.

93 For the author Irish law has recently served as a striking example how difficult it may be to find out what the law is: The resolution to remove a director requires "extended notice" (Art. 182 Companies Act) which means 28 days (Art. 142 Companies Act). Does that mean that he is already removed or that he can continue to act on behalf of 


\section{c. The Right to Give Instructions}

The single shareholder of a subsidiary usually has some ideas how to run the subsidiary which may not always be appreciated by the director. The threat to immediately remove him or her (see above) may in many cases be exaggerated and impractical. The search for and appointment of a new, sufficiently qualified director in a foreign country is not a task to be taken too frequently. Hence, a clear rule on who has the legal right to decide is helpful. Article 23 (1) SUP Proposal gives the answer: "The single-member shall have the right to give instructions to the management body."

Again, this provision may be under-estimated for company lawyers from countries where such a right to give instructions is already common ground. ${ }^{94}$ But not every Member State has a clear-cut rule like Article 23 (1) SUP Proposal. For the Netherlands it has been reported that there is no legal right to give binding instructions; it can, however, be stipulated in the articles of association. ${ }^{95}$ This would, however, already come as a surprise to, let's say a German parent unaccustomed to the need to stipulate this issue in the articles. The explicit provision of Article 23 (1) SUP Proposal again helps a foreign single shareholder to quickly determine his or her legal position.

The fact that a shareholder uses the right to give instructions may, however, be dangerous regarding the content of Article 22 (7) SUP Proposal. ${ }^{96}$ According to this provision a person whose directions or instructions the directors are accustomed to follow shall be considered a director. This seems to be related to the English concept of the 'shadow director'. In English law, however, there is an exception to protect parent companies from being automatically qualified as shadow director (Article 251 Companies Act). This should also be introduced in the SUP Proposal.

\section{d. Preliminary Conclusion}

The SUP Proposal offers considerable advantages for cross-border group management by clearly regulating the relationship between the single share-

the company during the 28 days period? Be that as it may be, in an SUP a quick look in Art. 22 (5) SUP Proposal would be sufficient.

94 For instance in Germany where there is an instruction right in private companies (cf. $\$ 37$ (1) GmbH-Gesetz).

95 Sven Hirschfeld, 'Der einheitliche SPE-Konzern im europäischen Binnenmarkt' (Baden-Baden, 2015) p. 55.

96 Christoph Teichmann/Andrea Fröhlich, 'Societas Unius Personae (SUP) - Facilitating Cross-Border Establishment', [2014] Maastricht Journal of European and Comparative Law (MJ) 536, 541. 
holder and the director of the subsidiary. ${ }^{97}$ Other issues which might have been solved in the framework of the EPC - such as the possibility to allow a director to acquire a minority share in the subsidiary and the problem of intra-group transactions - are not solved due to the restricted scope of the SUP Proposal. The European legislator should further investigate possibilities to offer a reliable framework for cross-border group management - if not in the SUP Directive (which seems to be the regrettable tendency in recent negotiations within the Council) in a future act on the group interest.

\section{EU Initiative on the Group Interest}

It has not passed unobserved that the SUP Proposal - notwithstanding the fact that it addresses some group-related aspects - finally offers only an incomplete framework for cross-border group management. ${ }^{98}$ The right to give instructions, as fundamental as it may be for intra-group management, cannot be without limits. The boundaries of the right to give instructions need to be drawn by EU law. ${ }^{99}$ Instead, the SUP Proposal leaves this central issue to national law (Article 23 (2) SUP Proposal). One can politically understand the hesitance of the European Commission to deal with these boundaries in the SUP Proposal, because they touch another issue which should be addressed in a separate legal act: the group interest.

In its Action Plan, the Commission declared its intention to introduce an initiative regarding the recognition of the concept of 'group interest'. ${ }^{100}$ German group law will be of limited use in this respect since it only covers public companies whereas the far more pressing issue is to regulate a framework for the typical subsidiary which is a closed corporation. A better starting point seems to be the French Rozenblum case whereby the parent will not be in breach of duty if it has given instructions to the subsidiary based on a coherent group policy which in the long run balanced the interests of the parent and the subsidiary. ${ }^{101}$ This discussion has only just begun and shall not be further

97 See also M. Ph. Weller/J. Bauer (above no. 41) 6, 28/29.

98 Peter Hommelhoff, 'Die Societas Unius Personae: als Konzernbaustein momentan noch unbrauchbar', [2014] GmbH-Rundschau, 1065. M. Ph. Weller/J. Bauer (above no. 41) 6, (28/29).

99 Christoph Teichmann, 'Europäische Harmonisierung des GmbH-Rechts', [2014] Neue Juristische Wochenschrift, 3561, 3564.

100 Action Plan (see above no. 40), p. 15.

101 For a more elaborated analysis see Conac (above no. 44). The Rozenblum formula was also the starting point for the proposal published by Forum Europaeum Corporate Group Law (above no. 25). 
elaborated in this article. ${ }^{102}$ It may lead to the conclusion that the SUP Proposal was not the appropriate framework for tackling the group issue at all. The European Commission and the Member States should, however, not drop the issue. Corporate groups, be they large or small, have a legitimate expectation to be taken seriously by European Company Law.

\section{Conclusion}

This article elaborated the interconnection between corporate groups and EU company law. It first refers to the recent SUP Proposal which, to a considerable extent, helps to facilitate the establishment and management of crossborder groups. It thereby takes account of a general shift in academic literature on groups from the traditional protective approach to a perspective which is focusing on the enabling character of group law. The article continues with an analysis of the EU freedom of establishment arguing that the creation of a cross-border group is an act which falls under the scope of Articles 49 and 54 TFEU. Secondary law helping to facilitate the establishment and management of corporate groups in the sense of 'enabling law' consequently is fully compatible with the competence of Article 50 TFEU to enact directives in order to attain freedom of establishment. Basic features of such an enabling law are the right of the single shareholder to appoint and remove directors and to give instructions to the director. A problem which remains to be solved is the legal framework of the right to give instructions which could balance the legitimate expectations of outsiders (in particular creditors) and the interest of the parent to coherently manage the group. To design legislative action on the group interest will be the European Commission's major challenge for the foreseeable future.

102 See, however, the proposal of an international group of company law experts published in this issue of ECFR. 